\title{
Magyar László megismerésének útja itthon és külföldön
}

\section{How László Magyar Became Known in Hungary and Abroad}

\section{Összefoglalás}

A tanulmány a Magyar László földrajzi felfedezó, Afrika-kutató születésének 200. évfordulóján megtartott konferencián, Szombathelyen, 2018. december 14-én elhangzott, key note minôsítésú, indító elôadás szerkesztett változata, melyet a szerzô kiegészített a neves kutató életrajzával és az ünnepi eseménysorozat beszámolójával. Az írás a Magyar László munkásságával kapcsolatos hazai és külföldi kutatások eredményeit adja közre, összegyújtve a fellelhetô, bőséges szakirodalmat.

Kulcsszavak: Magyar László, Afrika, Angola, ovimbundu nép, afrikai rabszolga-kereskedelem

\section{Summary}

This study is the edited version of a keynote speech delivered on 14 December 2018, at a conference held to commemorate the 200th anniversary of the birth of László Magyar, an explorer of Africa. The study is complete with his biography and a report of the events organised for the celebration. A summary is also given of the findings of Hungarian and international research on the work and accomplishments of László Magyar, supplemented by ample references.

Keywords: László Magyar, Africa, Angola, Ovimbundu people, African slave trade

Biernaczky Szilárd, Doct. Univ, CSc, nyug. egy. docens, szenior mb. elôadó, ELTE BTK Történeti Intézet (bierszilard@gmail.com). 
Magyar László munkásságának megismerése Magyarországon (majd nem sokkal késôbb külföldön) akkor kezdődött, amikor 1852-ben egyik elsôként hazajutott naplókivonata (Dél-Afrika belsejében tett utazásom rövid kivonata) és apjának írt levelei a Magyar Hirlapban (sic!) megjelentek. A következó években hazai és külföldi lapok, folyóiratok sora adott hírt afrikai utazásairól. Magyarul az Új Magyar Muzeum, a Pesti Napló, a Budapesti Szemle, az Akadémiai Értesitô, az Erdélyi Muzéum, a Vasárnapi Ujság, a nagyszebeni Transylvania, a Magyar Sajtó, a Budapesti Hirlap, de még a Hölgyfutár is, idegen nyelveken mindenekelőtt a Gothában kiadott Petermanns's Geographische Mittheilungen, valamint a Pester Lloyd, a Pest-Ofner Zeitung vagy a Mittheilungen der Kaiserlich-Königlichen Geographischen Gesellschaft, sốt, a londoni és párizsi kiadású Athenaeum, továbbá a Daily News (bár ezeket szomorúságomra a megjelölt helyeken nem találtam!), és persze hivatalos vagy szakmai portugál, francia és angol kiadványok, mint a Boletim e Annales do Conselho Ultramarino, az Oficial do Governo Geral da Província de Angola, a Nouvelles annales de voyages de la Géographie, de l'Historie et de l'Archéologie, a Revue moderne, a Le Tour de Monde vagy éppen a Journal of Royal Geographical Society adnak hírt rövidebb-hosszabb formában, esetleg napló- vagy levélrészleteket is közölve, a magyar felfedezó utazóról.

Az eddigi felsorolásra figyelmezve tehát nem egészen osztozhatunk abban a megállapításban, amely már Thirring Gusztáv korai írásaiban (1884; 1888) megfogalmazódik. Már amennyiben Magyar László jeles életmúve árnyékban maradt, és amelyet még inkább elhomályosított a Magyar halála után majd harminc évvel az azonos terepeken járó Serpa Pinto portugál ezredes kétkötetes beszámolója. Lásd ennek kapcsán Richard Francis Burton megjegyzéseit. Ugyanis ez a Livingstone-méretú brit felfedezô utazó Pinto könyvéról írva részletes kritikát, erôsen kifogásolja, hogy a portugál ezredes nem ismerte vagy nem akarta ismerni Magyar munkáját. De Ecsedy Csaba is felveti ezt a gondolatot, még szúkebbre vonva a magyar utazó hazai és nemzetközi ismertségének körét, és erôteljesen hangot adva annak, hogy a nemzetközi tudomány Magyar egyedülálló értékeit (máig csak nála bemutatott népek, a rabszolga-kereskedelemre vonatkozó egyedülálló ismeretek, a bihéi ovimbundu nép teljes körú és még a változások elôtti, korai leírása stb.) a nemzetközi tudomány máig nem ismerte fel (1969; 1978).

Krizsán László is többször hangot ad ennek a kárhoztató megítélésnek. Magyar-monográfiájában (1983) a következóket írja: „...nemcsak arcképét, de életmúvét sem ismerjük jelentôségéhez méltóan és igazán. Nem ismeri - elsôsorban nyelvi okokból - a világ tudományos közvéleménye, és nagyon keveset tudnak a legnagyobb magyar felfedezôrôl korunk magyarjai. Pedig Magyar László életmúve nagyobb figyelmet érdemel. Nagyobb figyelmet az egyetemes Afrika-tudomány részéról, és nagyobb figyelmet azon nemzedék részérôl, melynek valós értékeit és alkotókészségét az is meghatározza, hogy mennyit képes meríteni nemzeti tudományunk gazdag örökségéból és az örökhagyók példájából” (Krizsán, 1983:10-11).

Kétségkívül mindhármuknak igazuk van abban a tekintetben, hogy sem a kontinens belsejébe elsôként behatoló skót felcserhez, Mungo Parkhoz, sem még inkább David Livingstone-hoz mérhetô, világszerte mindmáig éló kultusz nem veszi körül a 


\section{Biernaczky Szilárd: Magyar László megismerésének útja itthon és külföldön}

honi berkekben oly jelentôsnek tekintett magyar Afrika-kutatót. Mindemellett a kép általuk (és mások által is) túl sötétre festett, mivel - amint ezt késóbb látni fogjuk - a csonkán maradt életmú, a hiányzó angol nyelvú fordítások mellett és ellenére Magyar László a 19. század második felében, majd a múlt században szellemi hagyatéka által mindinkább részesévé vált az egyetemes tudományosságnak.

De még mielôtt rátérnénk Magyar László múvelôdéstörténeti utóéletének vázlatos felvillantására, egy pillanatra tartsunk még tükröt magunk elé az ô produkcióját és sorsát számba véve. Sok éve már, hogy a kezembe került a patinás brit kiadó, a Frank Cass African Studies címú katalógusa. S e füzetben több száz 18. és fôleg 19. századi angol, francia, portugál, német és más nyelvú afrikai utazási beszámoló címével voltam kénytelen szembesülni. Vagyis a mi ragyogó felfedezó-utazónknak egy ilyen hatalmas ismeretekkel telt hajóhad közepén kellett és kell kormányoznia saját terepmunka-eredményekkel felszerelt szkúnerét (sónerét), már ahogy ó maga említi e hajótípust a kalabári szultánra való hivatkozásai során.

Ami viszont szerencsétlen sorsát illeti, hát bizony aligha vigasztalhat bennünket, hogy hozzá hasonlóan elszánt utazók százai pusztultak el ifjú korukban a kontinens fertôzései, egészségtelen klímája, állatok vagy törzsek támadásai következtében. Hirtelenjében az egyébként is eredményeit, szemléletmódját tekintve Magyarral párhuzamba állítható és már említett Mungo Park jut eszembe, aki második útja során - keresve a Niger torkolatát -, már jóval a nagy kanyarulat után egy vélhetôen hauszák indította folyami támadás során fulladt a folyóba 35 éves korában, 1806-ban, vagyis nem sikerült a deltát elérnie. Ugyanígy aligha vigasztalhat bennünket az, hogy nem Magyar az egyetlen, akinek e kockázatos expedíciók során nagy értékú tudományos anyagai, jegyzetei, gyújteményei elvesztek.

Sajnálkozva, fájdalommal, akár mítoszokat is melengetve a szívünkben (hátha mégis megtalálható volna az a bizonyos kétládányi irat és könyv, amely a helybéliek értesítése szerint, halála után a Benguela és Mossamedes közötti, part menti házban elégett), nincs más lehetôségünk, minthogy megpróbáljuk - lám-lám, a mégiscsak rendelkezésre álló gazdag anyag folytán - legalább vázlatosan feltárni Magyar László munkásságának a megismerését, a magyar és a külföldi kulturális és tudományos élet véráramába való bekerülése útját. Ennek a folyamatnak bizonyos halovány és még nem igazán tudatos mozzanatai már Hunfalvy János, Thirring Gusztáv, Márki Sándor, Sámi Lajos, Jankó János és más 19. századi magyar szakírók múveiben is felfedezhetôk.

Thirring ugyanakkor a recepciókutatás talán legfontosabb területén is úttörô, amikor pl. nemcsak késối kötetében (1937), hanem egy korai tanulmányában (1888) már korabeli útleírások adataival veri vissza azt a vádat, hogy Magyar földrajzi nevei (illetve a mögöttük rejlő helység-, terület-, hegy-, völgy- és vízrajzi helyek helybéli megjelölései) légból kapottak.

Természetesen nincs módunk itt a Magyar híradásainak ideje (1852-1864), majd a halálától a századfordulóig terjedó idôszak viszonylagosan reagálásokban gazdag idôszakát részletesen ismertetni. Mindenesetre megemlítjük, hogy két könyvének szerkesztôje, Hunfalvy János akadémikus a legszorgalmasabb a tájékoztatás területén, hiszen tôle Magyarról tucatnál több megnyilvánulás lát napvilágot magyarul és néme- 
tül. Közöttük, az ismertetések mellett, kritikai hangot megütô elemzési kísérleteket is találhatunk. Különösen a nagy könyv bevezetôjében és azokhoz készült jegyzeteiben kifogásolja Magyar szakmai felkészületlensége mellett pl. nyelvi-nyelvészeti adatolásainak módszerét, és számos helyen némi didaktikussággal próbál hátteret adni a már ismert nemzetközi szakirodalomból utazónk leírásaihoz. Mindemellett ezeknek az elsô reakcióknak a zöme az elsó egy-két évtized során egyrészt rácsodálkozás az ismeretlen világra, másrészt az egzotikusnak érzékelt utazások ismertetése az immár rendelkezésre álló, hazaküldött iratok alapján, mindenféle kritikai megjegyzés nélkül.

Hadd idézzük itt Dinome abbé, az egyébként felderíthetetlen hátterú francia földrajzi szakíró megállapítását (1860), amelyet Hunfalvyra alapozva fogalmaz meg (e szerzó egyébként két évvel korábban lefordította a Petermann-féle évkönyvben 1857ben megjelent, Magyar naplókivonataiból készített összeállítást is franciára): „Bár tudjuk, hogy ez a könyv nem elégíti ki azt a mércét, amint e témát illetôen M. J. Hunfalvy is megjegyzi, hogy teljes mértékben megfeleljen a földrajztudomány csúcsainak (ami általában csak az utazási beszámolók nagyon kis számát jellemzi), azonban úgy véljük, hogy e mú nagyban hozzájárulhat ahhoz, hogy tovább építse mindazt, aminek a keresése során próbálnak (már az utazók-kutatók - B. Sz.) mindent megismerni az afrikai országokról és népekrôl, nemcsak azáltal, hogy szórakoztató olvasmánnyal szolgáljanak, de meg vagyunk gyôződve arról, hogy jelentôsen szélesíthetjük velük az Afrikával kapcsolatos ismereteinket, és korrigálhatjuk azt, amit már eddig megtudtunk. Ez az útleírás három részre oszlik, az elsó tartalmazza a Bihe-be utazás leírását, a kimbundák által elfoglalt különféle országok fizikai, politikai és társadalmi leírását, a második foglalkozik azokkal, akik a Mun Ganguella földeket lakják, a harmadik magában a Mombuella országgal" (Dinome abbé, 1860:349-354).

Nem véletlenül idéztük az utóbbi mondatot. Számos esetben ilyen és hasonló tévedések, félreértések tarkítják a Magyarra vonatkozó, egyébként pozitív hangvételú reagálásokat ebben a korai szakaszban. Hiszen a Mun Ganguella földek és Mombuella ország leírása csak terv volt és maradt. Vagyis az ismertetett monográfia nem állt három részból. Ha a második és harmadik része valóban elkészült, akkor az, sajnos, mint említettük már, lángok martalékává vált.

Ami ezeknek az elsố évtizedeknek a jelentôs hozadéka, az a számos híradás, ismertetés, kivonatolás, átírás mellett nem más, mint hogy német és francia nyelven is születnek Magyar könyveiból és naplókivonataiból - Dinomé említett német fordításból készített francia változata mellett - további idegen nyelvú Magyar-kiadások. Ezek szerepe azért rendkívül fontos, mert lényegében mindmáig ezek a közreadások adnak egyedül lehetôséget arra, hogy Magyar munkásságát külföldön megismerjék. A középpontban természetesen Hunfalvy monográfia-fordítása áll, illetve a két terjedelmesebb közlemény a Petermann-féle évkönyvben. A Hermann Wagner vagy Charles John Andersson (egyképpen 1863), majd Richard Oberländer (1874) szerkesztette népszerúsítô kötetekben, terjedelmesebb formában közreadott német nyelvú monográfiarészletek ugyancsak Magyar megismertetését szolgálták. És eközben, Dinomé abbé említett fordítását követôen, egy kétrészes, kivonatos, francia nyelvú fordítás is született (Reclus, 1868). Viszont nem tudjuk másképpen elkönyvelni, mint egy kimaradt 


\section{Biernaczky Szilárd: Magyar László megismerésének útja itthon és külföldön}

nagy lehetőséget, amennyiben a már ugyancsak említett Sir Richard Francis Burton lefordította Magyar könyvét a német változatból, de ennek kiadása (mivel nem a magyar szövegből született a fordítás!) megbukott az angol kiadók ellenállásán, jóllehet a német anyanyelvú Hunfalvy János készítette a német fordítást, vagyis hiba nemigen akadhat(ott) benne.

A 19. század második feléből még Ernst Behm belső Afrika földrajzi feltárásáról készített összefoglalóját (1858) említhetjük, aki részletesen megemlékezik Magyarról. A már említett R. F. Burton egy könyvében (1876) ugyancsak meleg hangon utal Magyar eredményeire. De a portugál Manuel Ferreira Ribeiro sem feledkezik meg róla könyvében (1885). Érdemes egyébként R. F. Burton sorait idézni: „Miközben a néhai Ladislaus Magyar szerint, aki korábban tájékoztatta a benguelai kormányt, a Casais (folyó - B. Sz.) mint ahogy elmondták neki, beleömlik, számos ismeretlen helyen átjutva, az Indiai-óceánba, (ő maga - B. Sz.) 1851-ben követte ezt a nagy fóeret, tovább, mint bármely más ismert utazó. Megtudta, hogy legtávolabbi kutatási pontján (a déli szélesség $6^{\circ} 30^{\prime} 43^{\prime \prime}$ és a keleti hosszúság G. 22º túl északkeleti irányt követ, és sok mérföldnyire nagy hullámokat vet, amelyek veszélyesek a csónakokra. A vizek továbbra is édesek, és egy olyan tóba ömlenek, amely más néven Mouro vagy Moura (Moráve vagy Marávi?), Uhanja vagy Uhenje (Nyanza?), és amelyről feltételezhető, hogy Urenge vagy Ulenge, amelyrôl Livingstone is hallott a déli szélesség 3 és keleti hosszúság (G.) $26^{\circ}$ körülrôl. A magyar utazó természetesen azonosította azt a mitikus Nyassza-tóval, amely oly rettenetes kárt okozott, és amely mostanában elmaradt. Magyar azt is állítja: »A különféle beszámolókból meggyőződhettem, hogy a Kongó emelkedik, egészen a Moluwa magas fennsíkját elfoglaló Inhanha nevú mocsárig, a lubák földjéig, egyesülve a régió számos patakjával; a forrástól számított ötnapi járóföldre mély, de keskeny folyóvá válik, amely nyugat felé folyik, sûrú erdókkel borított, sík vidéken keresztül, melynek északról és délrôl érkezô számos patakja a folyóba torkollik; aztán északnyugat felé fordul Kuango néven. "Itt találjuk a megfulladt földeket, a Livingstone-féle »szivacsokat «, ố azonban sokkal közelebb helyezte el a forrásokat délkeleti irányban” (Burton, 1876:183-184).

Ugyanakkor mindenképpen fel kell figyelnünk itt Burton jegyzeteire is, amelyból egyrészt kiderül, hogy Magyar könyvének angolra fordítását vélhetően elôször nem ó tervezte elkészíteni. Másrészt, hogy a brit utazó nemcsak Magyar könyvét, hanem más írásait is ismerte: „Szükségszerúen beszereztem Pestről Hunfalvy professzor engedélyét, aki 1859-ben kiadta a magyar és német változatot, a rendkívül érdekes kötet, Ladislaus Magyar egyetlen hagyatéka, angolra fordításához, hiszen az utazó 1864. november 19-én meghalt, miután Dél-Afrika nagy és korábban ismeretlen területeit kereste fel. A munkát R. C. G. O’Callaghan konzuli káplán végezte, és remélem, hogy hamarosan az általam készített jegyzetekkel megjelenik. Ez jól fog illeszkedni dr. de Lacerda Utazás a Cazembe földjeire c. múvéhez" (Lacerda portugál nyelvú könyvéből Burton publikált terjedelmes angol nyelvú kivonatot - B. Sz.).

Viszont mindezzel a gazdagságot sugárzó idôszakkal szemben a huszadik század, mondhatni, egyszerzôjú elsô évtizedeivel kell szembenéznünk magyar vonatkozásban. Mégpedig azért, mert Thirring Gusztáv néhány ugyancsak fontos cikke, tanulmánya 
mellett közreadva majd fél évszázados előkészületek után már említett monográfiáját, gyakorlatilag az egyetlen ekkor, aki érdemben, újdonságokat hozva foglalkozik Magyar munkásságával. A jeles tudós, akinek folyamatosan múvelt szakmája (statisztika, demográfia), jól tudjuk, lényegesen eltért ezúttal vállalt témájától, elsôként ad, máig is értékelhetően, alapos áttekintést és elemzéseket Magyar dokumentumainak földrajzi vonatkozásairól (a korábban súlyos kritika alá volt földrajzi nevek tekintetében összevetố vizsgálatok sorozatával igazolja Magyar afrikai helyneveinek helyességét), sôt megkísérli értékelni a múvek néprajzi adalékait is. Nem véletlen, hogy a 20. század második felében kivirágzó Magyar-kutatások fôszereplői minduntalan említik, hogy az érdemi munkálatok kiindulópontja csak Thirring monográfiája lehet. Így, amint említettük, 1937-ben közreadott jeles munkájában lelhetjük meg a Magyar Lászlóra vonatkozó szakirodalom módszeres feltárásának kezdetét is. Ố nem kevesebb, mint öt sûrú oldalon sorolja a vonatkozó kritikai írások adatait, mi több, az egyes tételek kapcsán több esetben kritikai értékelést is kapunk. Így például a Pester Lloyd 1856-os közleményéről megjegyzi: „Közöl képtelen dolgokat, azt állítja, hogy Magyarnak 50-nél több gyereke van. Nagy elismeréssel szól tudományos eredményeirôl.” Vagy a legutóbb Vajkai Zsófia által is elemzett Bánfi János-féle ifjúsági regényről (1892) megállapítja, hogy „Afrikai utazásait Magyar könyve és cikkei alapján ismerteti. A fiatalságát tárgyaló 1-9. fejezet, valamint a 21-25. fejezet meróben a fantázia szüleménye”.

Természetesen illenék itt még (és mégis) említeni Halász Gyula tanulmányát (1936), még inkább Bendefy-Benda László könyvét (1934), továbbá Kéz Andort, aki lexikonába (1937) beilleszti Magyar életrajzát, és könyvében is foglalkozik vele (1938). Azonban úgy véljük, a huszadik századi tudományosság jegyében a kizárólag ismertetésre és kivonatolásra alapozó, jól ismert adatokat megismétlő írások nem különösebben kelthetik fel a figyelmünket. Más kérdés, hogy az elsố világháború elôtti évtizedekben született, esetleges külföldi reagálások mindmáig nagyrészt felderítetlenek. Csak hazánkfia, Torday Emil nevét említhetjük, aki angol nyelvú írásaiban többször visszatér Magyar Lászlóra, megkísérli útjai során megtalálni elôdje terepeit, és többször foglalkozik az ún. dzsaga kérdéskomplexummal, aminek ismertetésére ezúttal nincs lehetôség. Itt említjük, hogy például sajnos mind a 19., mind a 20. századi portugál források jórészt megközelíthetetlenek, vélhetôen fơleg abból következóen, hogy a szükséges múvek digitalizálásában esetükben jelentôs lemaradások tapasztalhatók.

A második világháború után kezdődô és máig tartó, mintegy háromnegyed évszázados korszakot a Magyar-recepció folyamatos hazai és külföldi bővülése jellemzi. Fóleg az interneten, de folyóiratszámokban és könyvtári anyagokban újabb és újabb reagálásokra bukkanhatunk. A továbbiak során így csak egy igen vázlatos szemlét tudtunk elővarázsolni, elsôként a hazai, a következôkben a nemzetközi hozzájárulások tekintetében, törekedve persze arra, hogy a legfontosabb eredményeket hozó tudományos közlések kerüljenek elótérbe.

A nemrégiben Münchenben elhunyt Vajda László professzor értó és a nemzetközi ismertség korlátait elôtérbe helyezô, a néprajzi eredményekre is kitekintô életrajzi öszszefoglalását (1951) követôen elsôként Ecsedy Csaba magyarul és angolul is megjelent dolgozatát (1969; angolul: 1984) kell említenünk, amely számos tanulságos megálla- 


\section{Biernaczky Szilárd: Magyar László megismerésének útja itthon és külföldön}

pítást tartalmaz. A kongói felhajózás leírását tartalmazó naplókivonat kapcsán hívja fel a figyelmet az egykori törzsi fônökségek, királyságok leírásának fontosságára, a bomai rabszolgatelep/rabszolgapiacról adott leírását pedig igen magasra értékeli. Írásának mégis legfigyelemreméltóbb elemzéssora arra irányul, aminek feltárását egyébként már Thirring is megkísérli könyvében (1937:75-81), hogy bemutassa Magyar szellemi fejlődését, a haditengerészből hogyan válik kalandkeresố utazóvá, majd pedig a földrajzi és néprajzi tények autotidakta feltárójává.

Viszont minden bizonnyal Krizsán László (1929-2006) az, aki a legtöbbet foglalkozott Magyar László munkásságával. Számos írásában és az egykor a Szovjetunióban megvédett, itthon azonban a honosítás folyamatában elakadt nagydoktori disszertációjában is Magyar Lászlónak a rabszolga-kereskedelem kapcsán fellelhetô, újszerú megfigyeléseit igyekszik feltárni. Lásd a koncentrált vagy másként szúkülô rabszolga-kereskedelemre, vagy a rejtôzködô népekre, illetve a rabszolgaság elól elmenekült afrikaiak emelte titkos kilombók (tanyák) létére vonatkozó elméletét. Hazai kutatók egyfajta vulgár-marxizmust vetnek a szemére. Én megvallom, értékelve törekvéseit és figyelemfelkeltését, inkább arra gyanakszom, Krizsánnak nem állt módjában a korabeli nemzetközi kutatási eredmények szakirodalmához hozzáférni, és néha túlzó, sôt fantáziálásba hajló megállapításai elsôsorban ebbôl a tájékozatlanságból fakadnak. Bár tegyük hozzá azt is, ezek mindig az afrikai népek nagyrabecsüléséból fakadtak. Mindemellett levéltárosi-történészi szakmájához méltóan igen sok adatfeltárással is megajándékozta a hazai tudományosságot.

A korszerú hazai kutatások korát jelenti a nyolcvanas-kilencvenes évektôl keletkezett szakirodalom: Fodor István, Vajkai Zsófia, Sebestyén Éva, Nemerkényi Zsombor, Sárkány Mihály immár a legmagasabb szintú szakmai felkészültség jegyében tárt fel Magyar munkásságából egy-egy területet, szinte véglegesnek tekinthetô eredményekre jutva.

Így egyedülálló Fodor István angol nyelvú könyve, amelyben a kiváló nyelvész terepmunkásunk umbundu nyelvi adalékait veszi számba, dolgozza fel azt rendkívül sokoldalú, fonetikai, lexikológiai és grammatikai szempontok szerint, ráadásul teljes képet adva az umbundu nyelv nemzetközi szakirodalmáról. Hasonlóképpen nagy értékú Vajkai Zsófia kísérlete Magyarnak a hagyományos mezôgazdaságra vonatkozó adalékai feltárása (1989) tekintetében.

Sebestyén Évának angolai terepmunkásunk kézírásával kapcsolatos, hosszadalmas grafológiai elemzéseit, ôszintén szólva, nemigen tudom követni. Annál fontosabbaknak ítélem a három könyve $(2008 ; 2008 ; 2012)$ bevezetőiben adott sokoldalú elemzéseket. Különösen nagyra kell becsülnünk a monográfia betúhív kiadásához (2012) fúzött megállapításait, amelyek hôsünk kutatómunkájának különféle területeit tekinti át. Igen jelentôsnek véljük az ovimbundu nép Magyar által feljegyzett eredetmítoszának elemzését, részben a Silva Porto hatalmas kéziratanyagában megtalált két másik, rövidebb változat közreadását, illetve a szöveg történelmi, néprajzi, folklorisztikai háttérvizsgálatára vonatkozó kísérletét.

Nemerkényi Zsombor látszólag egy szúk terület, a földrajzi szakirodalomban mégiscsak igen jelentôs momentum, a mára már ismert két eredeti Magyar-térkép értékelé- 
sében járt kanosszát. Hiszen egyébként több szempontból is értékes disszertációjában a második térkép egy olyan változatát elemezte, amely, közben kiderült, nem az eredeti. Önkritikusan bevallva ezt (bár tudjuk, hogy az ilyen tudománytörténeti elcsúszások szinte természetesek az adatok feltárásának buktatói következtében), újabb elemzési kísérletét (2013) még újabbak követhetik. Miközben térképész kutatónk már a diszszertációjában megkezdett egy olyan lényeges munkálatot, amely Magyar írásainak várva várt kritikai kiadását elôlegezi: már amennyiben a nagy számban említett egykori földrajzi név mai változatainak listába szedéséból adott terjedelmes ízelítôt. Arról nem is beszélve, hogy eközben a legteljesebb szakirodalmi bibliográfiát is összeállította.

A második világháború utáni külföldi kutatási eredmények bemutatása, már amelyekre fény derült mindeddig, szinte csak nevek felsorolására szorítkozhat.

Három fontos angol kutató, Gladwyn Murray Childs (1949; 1964; 1970), Merran McCulloch (1951; 1952) és Adriann Edwards (1962) könyveit, írásait kell mindenképpen említenünk, mivel ôk az ovimbunduk, illetve szúkebben a Bihé királyság történelmével, földrajzi környezetével, társadalmi berendezkedésével, rokonsági rendszerével, néprajzával foglalkoznak, sôt, általános leírását (McCulloch) is megadják. Miközben valamennyien hasznosítják Magyar László adatait.

Angola történelmének különféle korszakait és jelenségeit dolgozza fel múveiben David Birmingham brit $(1965 ; 1976 ; 1981 ; 2015)$ és Beatrix Heintze német professzor (többek között 2004). Birmingham egy nemrégiben hozzám írt levelében írja, hogy Magyar könyvét még pályája elején, a hatvanas években olvasta nagy élvezettel.

De hasonlóképpen kell rövidre fogott fonalunkra felfúzni Jan Vansina neves tanítványa, Joseph C. Miller (1972; 1975; 1975; 1976; 1977; 1982), továbbá John Kelly Thornton (1978; 1988; 1991; 2004) vagy Inge Brinkman (2000) és mások nevét, akik Angola történelmét vizsgálva gyakran fókuszálnak a jaga (dzsaga) kérdéskomplexumra. Ugyanis az Magyar választott népe, a bihéi ovimbunduk szempontjából is fontos, hiszen eredetmítoszuk ehhez a 16. századig visszavezethetô, vad, erôszakos, állandóan pusztító harcokat kezdeményezô, rabló, fosztogató, de erôt sugárzó néphez kötôdik. Ide kell füznünk még ugyanakkor az Oral History Research iskolateremtô tudósának, Közép-Afrika történelme egyik legkiválóbb ismerôjének, a nemrégiben elhunyt Jan Vansina professzornak (1929-2017) jó néhány munkáját, mivel azokban számos alkalommal fedezhetô fel Magyar Lászlóra való hivatkozás, hiszen a több mint 50 jeles kutatót útjára indító mester a jaga-kérdéskörtôl, a jagák alapította Kasanje (ejtsd: Kasandzse) királyságon át a 16-20. századi kongói-angolai történelem számos mozzanatáig sokféle téma kidolgozására vállalkozott.

A német kutató, Roma Mildner-Spindler írta minden kétséget kizáróan az utóbbi két-három évtized egyik legfontosabb Magyar-tanulmányát (1996), amelyet a Vasi Szemlében megjelent tanulmányomban ismertettem. Kár, hogy doktori disszertációja és egy másik tanulmánya nem hozzáférhetô, amelyben feltételezhetốen további utalások lapulhatnak Magyar Lászlóval kapcsolatosan.

Aligha feledkezhetünk meg a már a harmincas években Londonba került Judit Listowel (Márffy Mantuano Judit, 1903-2003) munkájáról (1974), amelyben a késóbb véglegesen emigránssá lett, újságírói pályát választó arisztokrata származású magyar 


\section{Biernaczky Szilárd: Magyar László megismerésének útja itthon és külföldön}

bárónố vállalkozott az elsô jelentôs figyelemfelhívásra angol nyelvterületen, amikor Magyar Lászlót Livingstone-nal párhuzamba állítva mutatja fel olvasóközönségének (The Other Livingstone). A kötetet egyébként megkülönböztetett szakmai pontosság és igényesség jellemzi, mint szerzője más afrikai köteteit (lásd Tanzánia-könyvét, $M a$ king of Tanganyika, 1964, vagy Idi Amin ugandai diktátorral foglalkozó könyvét, Amin, 1973), hiszen pl. vállalkozott arra, hogy Angolában kiterjedt nyomozást folytasson Magyar nyomait felkutatandó, megtalálva annak feltételezett leszármazottait.

Természetesen igen gazdag - tematikailag kissé szélesebbre nyitott körben - a portugál kutatók hozzájárulása is vizsgálati terepünkhöz. Többek között az utazási irodalmat, a karavánkereskedelmet, a népességszám alakulását, az éhezés méreteit, az egészségügy (trópusi betegségek) problematikáit vizsgálják, és többnyire Magyar adatait is felhasználva, sokszor Silva Porto kapcsán. Maria Emília Madeira dos Santos (1986, Silva Porto kapcsán), José C. Curto (1992; 1999; 2005; 2011), Roquinaldo Amaral Ferreira (1999; 2006; 2011; 2012), az USA-ba szakadt Mariana P. Candido (2005; 2007; 2008; 2013), Maria da Conceição Neto (2012) vagy Constança do Nascimento da Rosa Ferreira de Ceita (2014) nevére hívhatjuk fel többek között a figyelmet.

Külön ki kell emelnünk Alexandra Aparíció nevét, aki nálunk tanult, több dolgozatában is (1995; 2001; 2017) foglalkozik Magyar Lászlóval, és az egyik legkényesebb kérdéssel néz szembe az egyik fontos írásában (1995): vagyis hogy miként, milyen megítélésben rajzolódik ki az afrikai, konkrétan az ovimbundu nép emberi arculata a bihéiek akkori fôvárosa környezetében letelepedô és a fơnöki családba beházasodó magyar kereskedô-utazó, utóbb audodidakta etnológussá lett útleíró munkáiban. Csak futólagosan tudjuk említeni, hogy számos más munka mellett sajnos nem tudtuk megszerezni többek között Ralph Delgado fontos könyveit (1940; 1944; 1945) vagy Joachim Rodriques Graça sokat hivatkozott, könyvméretú tanulmányát (1890) sem.

Szemlénk közvetlenül tudományos részének végére érve mondjuk el, hogy egy Sebestyén Évával folytatott, többmenetes eszmecsere során ô a Magyar-munkásság elterjedésének korai szakaszát látta kiemelkedôen fontosnak megvizsgálni. Én véleményével ellentétben, mivel a korai korszak inkább csak Magyar kivonatolásával és ismertetésével volt elfoglalva, a 20. században készült feltárásokban, elemzésekben, e korszaknak is fóleg a második világháború után kezdődố évtizedeiben látom a kutatásoknak azt az idôszakát, amelyre különösen nagy figyelmet kell szentelnünk, és amelynek feltárásában még sok a teendônk.

Vélhetốn a recepciókutatás különös fejezetének tekinthetjük, hogy Magyar László immár belépett a világirodalomba is. A Vasi Szemlében idézetet hoztunk Havas Antal 1895-ös elbeszélő költeményéből, amelynek nagyobb része Magyar angolai tevékenységét jeleníti meg Arany Jánosra ütô verselési stílusban. Az utolsó évek nagy eseménye viszont Ana Paula Tavares angolai költóasszony vállalkozása, amely Ozoro és Magyar szerelmét idézi fel szép költeményében, és amely immár két magyar fordításban is létezik, hiszen Rákóczi István nívós magyarítása mellé saját próbálkozásunk is felsorakozott. Elóbbi kiadásáról már tudunk, utóbbi az általunk rövidesen megindítandó új periodika, a Philologia Africana Letteraria Hungarica hasábjain lát majd napvilágot, számos néprajzi vonatkozású jegyzet kíséretében. 


\section{Polgári Szemle · 16. évfolyam 4-6. szám}

Nem lenne viszont teljes eme szemlénk, ha nem utalnánk meglepó mozzanatokra is Magyar László munkásságának utóélete tekintetében. Ugyanis a Magyar-szakirodalom bôvelkedik sajátos tudománytörténeti furcsaságokban. Néhány buktatóról már megemlékeztünk. Krizsán is poentírozza azt az egykori hamis hírt, miszerint „Magyar László fia, miután Bihében elfoglalta anyai nagyatyja trónját, bizonyos évi járadék ellenében felajánlotta az országot a Monarchiának" (Krizsán, 1983, 583. old.).

Thirring még két hírlapi kacsáról értesít minket: 1936-ban elterjedt a híre, hogy 45 évvel azelôtt a pesti éjszakában gyakran találkozhattak azzal a kis cigánybórú fiatalemberrel, akit királyfinak hívtak. Tóth Béla pedig arról ír, német lapok szerint Bihe trónján egy Magyar nevú fejedelem ül, illetve hogy gyönge egészsége helyreállítása céljából Kamerunban tartózkodik.

Nicolas de Kun, hazánkfia, világhírú geológusprofesszor, az afrikai ásványkincsek egyik legjobb korabeli ismerôje 1960-ban francia nyelvú Magyar-tanulmányában viszont még mindig Szabadkát jelöli meg Szombathely helyett Magyar születési helyének.

Isabel Burton 1893-ban, néhány évvel férje, Sir Richard Francis Burton halála után közzétett róla egy kétkötetes életrajzot, amelynek végén külön felhívja a figyelmet a Magyar-monográfia kiadatlanul maradt fordítására. Jóllehet ehhez a ma egy kaliforniai alapítványi archívumban őrzött kézirathoz nem lehet hozzájutni. (Azóta kiderült, hogy a fordítás elektronikus másolata zárt formában megtalálható az MTA Könyvtár kézirattárában.)

Többször összedugtuk a fejünket, mi, hazai kutatók, azon a furcsaságon elmélkedve, hogy vajon a kiváló Afrika-tudós, Wilfrid Dyson Hambly számos terepmunkán is alapuló és az ovimbundukra vonatkozó tanulmányaiban, illetve nagy terjedelmú könyvében miért nem használja fel Magyar adalékait, bár honfitársunk monográfiáját címként ismeri és említi.

1950-ben, az isten háta mögötti Northern Rhodesia Journal elsố évfolyamának elsố számában egy olvasó felteszi a kérdést: Richard Burton az egyik könyvében (Lacedra' Journey to Cazembe in 1798) szereplố térképen feltüntet két, Magyar László, illetve Silva Porto utazásaira vonatkozó útvonalat, s vajon mit tudhatunk e két utazóról. A felkért könyvtáros válaszában többek között minden német nyelven ismerhető Magyar-forrást felsorol.

A legmeglepóbb adat viszont: Verne Gyula, minden idók legolvasottabb ifjúsági írója az Öt hét léghajón címú könyve végén, az utazási irodalmi adatok sorában felsorolja Magyar könyvét.

És utoljára: jóllehet Ferenc József, illetve a Monarchia nem nyújtott támogatást a magára hagyott Magyar Lászlónak, Alexander Brandt és Paul Kainbacher 2010-es bibliográfiájában (Österreichische Forscher und Reisende in Afrika vor 1945) Magyar László osztrák utazóvá lép elô.

\section{Magyar LÁSZló ÜZENETE A MÁNAK}

Elsô üzenet: együttmúködés Afrikával: José Eduardo Agualusa nemzetközi hírú angolai író Tavares említett poémájára reflektálva azt írja, Magyar terepmunkája azért egyedülálló mind a mai napig, mert azt nem valamely európai állam, intézmény, társaság, 


\section{Biernaczky Szilárd: Magyar László megismerésének útja itthon és külföldön}

vállalkozás vagy személy, hanem egy afrikai törzsi király szponzorálta. Íme, Krizsán igazolása, amikor arról ír, az elsố együttmúködés a történelemben európaiak és afrikaiak között.

Második üzenet: a helyét keresô Magyar László ráébred az afrikai népek történelmének, kultúrájának, civilizációs produkciójának, társadalmi gyakorlatának szerepére, mint az emberiség összmúveltségének alkotórészére, és ezzel akár Leo Frobenius szemléletmódjáig mutat előre, aki az afrikai kultúra felértékelésével képes volt felszabadítani a négritude híres-nevezetes fôszereplôi, Aimé Césaire, Léopold Sédar Senghor és Léon Damas, majd sokan mások gondolkodását.

Harmadik üzenet: amint Alexandra Aparício is kiemeli dolgozatában (1995), Magyar László, beilleszkedve egy afrikai törzsi királyság emberi kapcsolatrendszerébe, feltárja - számos kritikai megjegyzés mellett is - az afrikai emberek tehetségét, emberi jó tulajdonságait, nagy melegséggel emlékezik meg utazásaihoz kapcsolódó kíséretének tagjairól, gyermek- és családszeretetérôl, vagyis utat mutat a minden (bármiféle) emberek közötti hídépítés lehetôségei és fontossága vonatkozásában.

Negyedik üzenet: az emberi kapcsolatok egy magasabb foka is megteremtődik Magyar László házasságával, amelynek Tavares ad hangot - természetesen erôsen idealizálva Ozoro hercegnó és a magyar utazó szerelmi kapcsolatát - egyfajta társadalmi tablót festố poémájában.

Ötödik üzenet: napjaink nagy nemzetközi társadalmi-politikai, sôt immár szinte történelmi méretú feszültséget okozó vitáiban rendkívüli jelentôsége van Magyar László azon szándékának, hogy szeretne hazatérni, fiát pedig magával hozni, mégpedig nem azért, hogy itt élhesse le az életét, hanem azért, hogy tanulhasson, majd visszatérve Afrikába népe múvelt vezetôjévé válhasson, és - teszem én hozzá - bölcsebb kormányzással elvezesse az ovimbundukat saját fajuk jobb megbecsüléséig, az okosabb boldogulásig, megtanítsa óket egy humánusabb, célratörôbb, érdemlegesebb gondolkodásmódra, és felszabadítsa az afrikai emberekben is rejtózó alkotói képességeket.

\section{FELHASZNÁLT IRODALOM}

Aparício, Maria Alexandra (1995): Um Húngaro entre Bienos em Meados do Século XIX: Interpretação e Análise das suas Relações. In: Actas do Seminário. Encontro de povos e culturas em Angola. Luanda, 3 a 6 de Abril de 1995. Comissão Nacional para as Comemorações dos Descobrimentos Portugueses, Lisbon, 391-403.

Aparício, Maria Alexandra (2001): Ismeretlen dokumentumok Magyar Lászlóról. Ethnographia, 112. évf., 1-2. sz., 223-243.

Aparício, Maria Alexandra - Cuango-Mutombo, Tiago (2017): Mandume, símbolo de la resistencia de los Owawambo. Santiago, No. 146, 384-397. (Magyarról: 386.)

Behm, Ernst (1858): Süd-Afrika im Jahre 1858. Eine geographische Skizze der neu erforschten Regionen des Innern. Vornähmlich nach Dr. D. Livingstone. Petermann's Geographische Mittheilungen, Band IV, 177-226. (Magyarról: 177, 187, 195-196, 198, 207, 213-216, 225.)

Bendefy-Benda, László (1934): Magyar László. Tizenöt év Dél-Afrikában. Budapest.

Biernaczky Szilárd (2011): Még egyszer Magyar Lászlóról. Magyar Tudomány, 172. évf., 6. sz., 710-716. Biernaczky Szilárd (2014): Magyar László eredeti szöveggel. Magyar Tudomány, 175. évf., 6. sz., 673-678.

Biernaczky Szilárd (2018): Magyar László szellemi hagyatékáról. Az elvégzett és az el nem végzett kutatási feladatokról - születése 200. évfordulóján, Vasi Szemle, 74. évf., 5. sz., 523-550. 


\section{Polgári Szemle · 16. évfolyam 4-6. szám}

Biernaczky Szilárd (2018): Magyar László néprajzi gyújtései. Honismeret, 66. évf., 6. sz., 3-9.

Biernaczky Szilárd (2019): Népköltészet, zene és tánc Magyar László munkásságában. Irodalmi Jelen, 19. évf., 213-214. sz., 176-199.

Biernaczky Szilárd (2019): Magyar László és a természettudományok. Afrika Tanulmányok, 13. évf., 3-4. sz., $67-82$.

Biernaczky Szilárd (2019): Magyar László és Ozoro hercegnố szerelme (Ana Paula Tavares angolai költônố poémájának fordítása néprajzi magyarázatokkal és dokumentációval). Vasi Szemle, 72. évf., 4. sz., 463-481.

Birmingham, David (1965): The Date and Significance of the Imbangala Invasion in Angola. Journal of African History, Vol. 6, No. 2, 143-152.

Birmingham, David (1966): Trade and conflict in Angola. The Mbundu and their neighbours under the influence of the Portuguese, 1483-1790. Clarendon Press, Oxford (portugálul lásd: 2004).

Birmingham, David (1976): The Forest and the Savanna of Central Africa. In: J. D. Fage - Roland, Oliver (eds.): The Cambridge History of Africa, c. 1790 - c. 1870. Cambridge University Press, Cambridge, 222269. (study), 512-514. (bibliographical essay).

Birmingham, David (1981): Central Africa to 1870. Zambezia, Zaire and the South Atlantic. Chapters from the Cambridge History of Africa, Cambridge, Cambridge University Press. (Magyarról: 113, 115, 156, 162, 171.)

Birmingham, David (2015): A Short History of Modern Angola. Oxford University Press, Oxford. (Magyarról: 27, 42-44, 51, 140.)

Brandt Alexander - Kainbacher Paul (eds.) (2010): Magyar, Ladislaus. In: Österreichische Forscher und Reisende in Afrika vor 1945 Eine Biographie und Bibliographie von A-Z. Baden. (Magyar László mint osztrák utazó.)

Brinkman, Inge (2000): Ways of Death: Accounts of Terror from Angolan Refugees in Namibia. Africa, Vol. 70, No. 1, 1-24. (Több helyen hivatkozik Magyar könyvére.)

Burton, Isabel (1893): Life of Captain Sir Richard Burton. 2. vol., Chapman and Hall Ltd., London.

Burton, Richard Francis Sir (1873): The Lands of Cazembe. Lacerda's Journey to Cazembe in 1798. Royal Geographical Society - John Murray, London.

Burton, Richard Francis Sir (1876): Two Trips to Gorilla Land and the Cataracs of the Congo. Vols 1-2, Sampson Low, Marston, Low, and Searle, London. (Magyarról számos helyen.)

Burton, Richard Francis Sir (1881): How I crossed Africa, by Major Serpa Pinto. Translated from the Author's MS. by Alfred Elwes, in 2 vols. (Sampson Low). The Academy, May 21, No. 472, 365-367. (Magyarról fontos mondat: 366 .)

Burton, Richard Francis Sir m. s. Monográfia angol fordítása Magyar László könyvének német változatából, Metcalfe Collection, Huntington Library, San Marino, California.

Candido, Mariana P. (2005): Usurping Freedom: Processes of Enslavement. In: Benguela's Hinterland, 1780 1850. (Magyarról számos helyen.)

Candido, Mariana P. (2007): Merchants and the Business of the Slave Trade at Benguela, 1750-1850. African Economic History, Vol. 35, 1-30.

Candido, Mariana P. (2008): Trade, Slavery, and Migration in the Interior of Benguela: The Case of Caconda, 1830-1870. In: Heintze, Betrix - Open, Achim von (eds.): Angola on the move. Angola em movimento. Transport Routes, Communications, and History. Verlag Otto Lembeck, Frankfurt am Main, 63-84 (preliminary electronic version, 2004).

Candido, Mariana P. (2015): An African Slaving Port and the Atlantic World. Benguela and Its Hinterland, Cambridge University Press, New York.

Childs, Gladwyn Murray (1949): Umbundu Kinship and Character. Oxford University Press for International African Insitute, London.

Childs, Gladwyn Murray (1964): The Kingdom of Wambu (Huambo): A Tentative Chronology. Journal of African History, Vol. 5, 367-379.

Childs, Gladwyn Murray (1970): The Chronology of the Ovimbundu Kingdoms. The Journal of African History, Vol. 11, No. 2, 241-248.

Curto, José C. (1992): A Quantitative Reassessment of the Legal Portuguese Slave Trade from Luanda, Angola, 1710-1830. African Economic History, No. 20, 1-14, 16-25. 


\section{Biernaczky Szilárd: Magyar László megismerésének útja itthon és külföldön}

Curto, José C. (1999): The Anatomy of a Demographic Explosion: Luanda, 1844-1850. The International Journal of African Historical Studies, Vol. 32, No. 2-3, 381-405.

Curto, José C. (2005): Resistência à escravidão na África: o caso dos escravos fugitivos recapturados em Angola, 1846-1876. Afro-Asia, Vol. 33, 67-86.

Curto, José C. (2011): Alcohol under the Context of the Atlantic Slave Trade. The Case of Benguela and its Hinterland (Angola). Cahiers d'Études Africaines, No. 201, 51-85.

Delgado, Ralph (1940): A famosa e histórica Benguela: catalogo dos governadores (1770 a 1940). Governo Geral da Província de Angola, Benguela/Luanda, 536. (A híres és nevezetes benguelai kormányzók ismertetése.)

Delgado, Ralph (1944): Ao Sul do Cuanza (Ocupação e aproveitamento do antigo Reino de Benguela). 2. vol., Lisboa. (A Quanza folyótól Délre. A régi benguelai királyság elfoglalása és kiaknázása.)

Delgado, Ralph (1945): O Reino de Benguela: do Descobrimento à Criação do Governo Subalterno. Beleza, Lisboa. Delgado, Ralph (1948-1955): História de Angola. 4 vol., Edições do Banco de Angola, Benguela/Lobito.

Dinomé abbé (1858): Magyar, László: Résumés des voyages exécutes dans l'Afrique Australe en 1848, 1849 et 1852. In: Dinomé abbé (ford., szerk.): Nouvelles annales de voyages de la Géographie, de l'Historie et de l'Archéologie. Tome IV, [sixième series - quatrième année], 5-54. (Petermann 1857 fordítása.)

Dinomé abbé (1860): Publication du premier volume de Ladislaus Magyar. Nouvelles Annales des Voyages, Tome 1., 349-354.

Ecsedy Csaba (1969): Magyar László: 1818-1864. Ethnographia, 53. évf., 4. sz., 557-564.

Ecsedy Csaba (1984): An African Hungarian: László Magyar (1818-1864). Africana Budapest, 1. sz., 9-23.

Edwards, Adrian (1962): The Ovimbundu under Two Sovereingties: a Study of Social Control and Social Change among a People of Angola. OUP for the IAI, London, VIII, 169. old.

Ferreira De Ceita, Constança do Nascimento da Rosa (2014): Silva Porto na África Central - Viye / Angola: história social e transcultural de um sertanejo (1839-1890). Tese de Doutoramento, Universidade Nova de Lisboa, Lisboa, 325. (Sok helyen idézi Magyar Lászlót.)

Ferreira, Roquinaldo (1998-1999): Escravidão e revoltas de escravos em Angola (1830-1860). Afro-asia, Vol. 21-22, 9-44. (Számos helyen idézi Magyart.)

Ferreira, Roquinaldo (2006): Atlântica: A Micro-Escala do Tráfico de Escravos em Benguela, séculos XVIII-XIX. Tempo, Vol. 10, No. 20, 23-49.

Ferreira, Roquinaldo (2011): The suppression of the slave trade and slave departures from Angola, 1830s-1860s. A supressão do tráfico de escravos em Angola (ca. 1830-ca. 1860). História Unisinos, Vol. 15, No. 1, 3-13.

Ferreira, Roquinaldo (2012): Cross-Cultural Exchange in the Atlantic World: Angola and Brazil During the Era of the Slave Trade. Cambridge University Press, Cambridge.

Fodor, István (1977): The Use of L. Magyar's records (1859) for the History of Umbundu. Studies in African Linguistics, Vol. 8, No. 7, 63-71.

Fodor, István (1983): Introduction to the History of Umbundu. László Magyar's Records (1859) and the Later Sources. Akadémiai Kiadó, Budapest.

Graça, Joaquim Rodrigues (1890): Expedição ao Muata yanvua, Diario. Boletim da Sociedade de Geografia de Lisboa, Ser. 9, No. 8-9, 365-466.

Halász Gyula (1936): Magyar László (1820-1864). In: Öt világrész magyar vándorai: magyar felfedezók Benyouszkytól napjainkig. Grill Károly, Budapest, (Magyarról: 49-60).

Hambly, Wilfrid Dyson (1934): The Ovimbundu of Angola. Field Museum of Natural History, Chicago.

Havas, Antal (1895): Afrikai képek. Különös tekintettel Magyar Lászlóra. Krausz-Fischer, Szabadka.

Heintze, Beatrix (ed.) (2004): Pioneiros Africanos: Caravanas de carregadores na África Centro-Ocidental (entre 1850 e 1890). Tradução de Marina Santos. Editorial Caminho, Lisboa.

Kéz Andor (1937): Magyar László. In: Felfedezốk lexikona. Franklin Társulat, Budapest, 87-89.

Kéz Andor (1938): Magyar László küszködése. In: Észak-és Dél-Afrika. A Föld felfedezói és meghódítói 2. Révai Irodalmi Intézet, Budapest, 302-313.

Krizsán László (1975): „Homo Regius” Afrikában. Emlékezés David Livingstone halálának 100. évfordulójára. MTA Afro-Ázsiai Kutató Központ, Budapest (Tanulmányok a fejlődô országokról, 78; angol nyelven is; Petermann véleménye Livingstone és Magyar földrajzi adatközléseirôl: 39-42.) 
Krizsán László (1982): Társadalmi struktúra, tulajdonformák és életmód a Kimbundu (Ovimbundu) nép társadalmában a XIX. század közepén - Magyar László kutatásai alapján. Akadémiai doktori disszertáció, Budapest (oroszul is).

Krizsán László (1983): Magyar László. A múlt magyar tudósai 11., Akadémiai Kiadó, Budapest.

Krizsán László (1988): Magyar László Afrika-kutató (1818-1864). Elhagyatva: tündökló életmû sötét háttérrel. Vasi Szemle, 42. évf., 2. sz., 233-246.

Krizsán László (1993): Elsố együttmúködés a történelemben fehér és fekete bôrúek között Afrika tudományos megismerésében. Földrajzi Múzeumi Tanulmányok, 12. sz., 15-22. [Utalás: Vajkai, Zs. (1997): Um Húngaro em Angola. 373.]

Krizsán László (1993): Kilombó-közösségek az afrikai társadalmak önigazgatású mikrobázisai a XIX. században. Vasi Szemle, 2. sz., 205-219.

Krizsán László (1994): A fekete földrész vándora. Szemelvények Magyar László afrikai útleírásaiból. Terra Print, Budapest.

Kun, Nicolas de (1960): La vie et le voyage de Ladislaus Magyar dans l'interieur du Congo en 1850-1852. Acad. Royale des Science d'Outre-Mer, Bull. des Séances, Vol. 6, No. 4, 605-636.

Listowel, Judit (1974): The Other Livingstone. Julien Friedmann, London (Magyar Lászlóról: 74-113, 132145, 234-238, 247).

Magyar László (2012): Magyar László utazása Dél-Afrika belsejében az 1849-1857 években. Balassi Kiadó - Magyar Tudományos Akadémia Könyvtára, Budapest.

McCulloch, Merran (1951): The Southern Lunda and Related Peoples. International African Institute, London (Ethnographic Survey of Africa) (említi Magyart).

McCulloh, Merran (1952): The Ovimbundu of Angola. International African Institute, London (Ethnographic Survey of Africa, West-Central Africa, Part II).

Mildner-Spindler, Roma (1987): Grundzüge der ethnischen Entwicklung im Territorium Angolas, ethnische Gemeinschaften und ethnische Prozesse von den Anfängen bis 1960. Univ., Diss. A. Leipzig (Nicht f. d. Austausch).

Mildner-Spindler, Roma (1993): Ethnien im zentralen Angola - Anmerkungen zur ethnischen Geschichte der (Ovi-) Mbundu (bis zu den 60er Jahren unseres Jh.). DASP-Hefte, krt Nr. 41/42, 23-50.

Mildner-Spindler, Roma (1996): Entdecker oder Abenteurer? Die Forschungen László Magyars (18181864) in den inneren Gebieten Angolas. Paideuma, Bd. 42 (Zur Geschichte der Afrikaforschung), 105140.

Miller, Joseph C. (1972): The Imbangala and the Chronology of Early Central African History. The Journal of African History, Vol 13, No. 4, 549-574.

Miller, Joseph C. (1975): Nzinga of Matamba in a New Perspective. The Journal of African History, Vol. 16, No. 2, 201-216.

Miller, Joseph C. (1975): Legal Portuguese Slaving from Angola. Some Preliminary Indications of Volume and Direction, 1760-1830. Revue Française d'Histoire d'Outre-Mer, Vol. 62, No. 226-227, 135-176.

Miller, Joseph C. (1976): Kings and Kinsmen. Early Mbundu States in Angola. Clarendon Press, Oxford.

Miller, Joseph C. (1977): Angola Before 1900: A Review of Recent Research. African Studies Review, Vol. 20, No. 1, 103-116.

Miller, Joseph C. (1982): The Significance of Drought, Disease, and Famine in the Agriculturally Marginal Zones of West-Central Africa. Journal of African History, Vol. 23, No. 1, 17-61.

Nemerkényi Zsombor (2008): Magyar László térképészeti munkájának összehasonlitó elemzése. PhD-értekezés, ELTE TTK Földtudományi Intézet, Budapest.

Nemerkényi Zsombor (2013): Magyar László térképei Kolozsvártól Gotháig. Geodézia és Kartográfia, 65. évf., 5-6. sz., 13-18.

Neto, Maria da Conceição (2012): In Town and Out of Town: A Social History of Huambo (Angola), 1902-1961. PhD Thesis, University of London.

Oberländer, Richard (1874): West-Afrika von Senegal bis Benguela. Verlag on Otto Spamer, Leipzig. (Magyarról: 406-456.)

Petermann, August - Magyar, László (1857): Die Reisen von Ladislaus Magyar in Süd Afrika Nach Bruckstücken seines Tagebuches. Petermann's Geographische Mittheilungen, Band III., 181-199. 


\section{Biernaczky Szilárd: Magyar László megismerésének útja itthon és külföldön}

Reclus, Onésime (1868): Voyage de Ladislas Magyar dans l'Afrique australe. Revue Moderne, Tome 44, No 1-2, 110-131, 251-272 (Magyar könyvének kivonata a német kiadás alapján).

Santos, Maria Emília Madeira dos (1986): Viagens e apontamentos de um portuense em África: Diário de António Francisco Ferreira da Silva Porto. Vol. I., leitura com introdução e notas por Maria Emília Madeira Santos. Biblioteca Geral da Universidade de Coimbra, Coimbra, 462. (Magyar: 441.)

Sebestyén Éva (2008): Kaland és kutatás Afrikában. Magyar László életrajza. ELTE Eötvös Kiadó, Budapest.

Sebestyén Éva (2012): Magyar László múve és életútja. In: Magyar László utazása Dél-Afrika belsejében az 18491957-es években. Balassi Kiadó - Magyar Tudományos Akadémia Könyvtára, Budapest, 7-58.

Sebestyén, Éva (2015): A sociedade ovimbundu nos relatórios de viagens do húngaro László Magyar: sul de Angola, meados do século XIX. História: Debates e Tendências, Vol. 15, No. 1, 83-100.

Sebestyén, Éva (2018): Escravização, escravidão e fugas na vida e obra do viajante-explorador húngaro László Magyar - Angola, meados do século XIX. In: Vieira Demetrio, Denise et al.: Doze capítulos sobre escravizar gente e governar escravo: (Brasil e Angola - séculos XVII-XIX). Mauad Editora, Rio de Janeiro, 291-312.

Tavares, Ana Paula (2018): Ozoro hercegnô és a magyari Magyar László szerelmes históriája. Ford. Rákóczi István, ELTE Eötvös Kiadó, Budapest (kétnyelvú Janus-kötet).

Thirring Gusztáv (1884): Bevezetés. Dél-Afrikában tett legnevezetesebb utazások rövid vázlata. In: Brozik Károly: Serpa Pinto utazása Afrikán keresztül. Az Atlanti Oczeántól az Indiai Oczeánig. Franklin Társulat, Budapest, 3-42.

Thirring Gusztáv (1888): Újabb adatok Magyar László életrajzához. Földrajzi Közlemények, 1. sz., 333-344.

Thirring Gusztáv (1937): Magyar László élete és tudományos múködése. Kritikai adalék a magyar földrajzi kutatások történetéhez. Magyar László kiadatlan írásaival, Kilián, Budapest.

Thornton, John Kelly (1978): A Resurrection for the Jaga. Cahier d'etudes Africaines, Vol. 18, No. 69-70, 223-227.

Thornton, John Kelly (1988): The Art of War in Angola, 1575-1680. Comparative Studies in Society and History, Vol. 30, No. 2, 360-378.

Thornton, John Kelly (1991): Legitimacy and Political Power: Queen Njinga, 1624-1663. Journal of African History, Vol. 32, No. 1, 25-40.

Thornton, John Kelly (2004): África e os africanos na formação do Mundo Atlântico, 1400-1800. Campus, Rio de Janeiro (angolul is).

Torday, Emil (1923): Bolyongások Afrikában. Három utazás az Egyenlitó vidékén. Világirodalom, Budapest (A hat világrész. Utazások és fölfedezések, 4).

Torday, Emil (1924): Afrikai emlékek. Egy Afrika-kutató naplójából. Világirodalom, Budapest (A hat világrész. Útikalandok és felfedezések 13).

Torday, Emil (1928): Dualism in Western Bantu Religion and Social Organisation. Journal of the Royal Anthropological Institute, Vol. 58, No. 1, 225-245.

Torday, Emil (1928): The Influence of the Kingdom of Congo on Central Africa. Africa, Vol. 1, No. 2, $157-169$.

Torday, Emil (1931): Central Africa. In: M. P. R. Smith (ed.): International Conference on African Children. London, 3-36.

Torday, Emil - Joyce, Thomas Athol (1905): Notes on the Ethnography of the Ba-Mbala. Journal of the Royal Anthropological Institute, Vol. 35, 398-426.

Torday, Emil - Joyce, Thomas Athol (1907): On the Ethnology of the South-Western Congo Free State. Journal of the Royal Anthropological Institute, Vol. 37, 133-155.

Vajda László (1951): Magyar László (1818-1864). In: Nagy Magyar utazók (19. század). Múvelt Nép, Budapest, $75-100$.

Vajkai Zsófia (1989): Notas de László Magyar explorador da Africa, sobre a agricultura dos povos angolanos. In: Estudos em Homenagem e Ernesto Vega de Oliveira. Instituto Nacional de Investigação Científica - Centro de Estudos de Etnologia, Lisboa, 825-850.

Vansina, Jan (1966): Kingdoms of the Savanna. A History of the Central African States until European Occupation. University of Wisconsin Press, Madison. (265. jegyzet: Magyar dél-afrikai utazása.) 
Vansina, Jan (1963): The Foundation of the Kingdom of Kasanje. The Journal of African History, Vol. 4, No. $3,355-374$.

Vansina, Jan (1966): More on the Invasions of Kongo and Angola by the Jaga and the Lunda. JAH, Vol. 7, 421-429.

Vansina, Jan (1996): Quilombos on São Thomé, or in Search of Original Sources. History in Africa, Vol. 23, $453-459$.

Vansina, Jan (2007): On Ravenstein's Edition of Battell's Adventures in Angola and Loango. History in Africa, Vol. 34, 321-347.

Vansina, Jan (2008): Communications between Angola and East Central Africa before c. 1700. In: Heintze, Betrix - Open, Achim von (eds.): Angola on the move. Angola em movimento. Transport Routes, Communications, and History. Verlag Otto Lembeck, Frankfurt am Main, 130-142.

Wagner, Hermann (ed.) (1863): Ladislau Magyar's Reisen in Benguela und Bihe. In: Belloni Du Chaillu, Paul - Magyar, Ladislaus - Andersson, Charles John: Afrika. III. Die neusten Entdeckungsreisen an der Westküste Afrika's. Bearb. von Hermann Wagner, Leipzig. (A teljes kötet terjedelme 288 oldal, Magyar László szövege: 184-268.; Magyar könyve 1859-ben megjelent német változatának kivonatos részei.) 